\title{
The influence of Belt and Road Initiative "concept of private higher education ideas
}

\author{
Haixia Wu \\ ${ }^{1}$ Hankou University, Wuhan 430212, China \\ ${ }^{2}$ School of economics and management, Tianjin College of Commerce, Tianjin 300000, China \\ a5871632@qq.com
}

Keywords: "The Belt and Road" concept; private universities; educational concept; influence

\begin{abstract}
With the development of society on the importance of education gradually improve, private university teaching level has received extensive attention in the society. As an important auxiliary force of China's higher education, play a role cannot be ignored in higher education. The idea of private higher education has become an important factor to determine the running level and teaching quality, based on the influence of "The Belt and Road" concept of private higher education ideas in-depth research, analysis of the connotation and advantages of "The Belt and Road" development strategy, at present people do exist in the concept of university education, and puts forward the measures to improve and perfect the private higher education idea under the background of new era, to improve the overall educational level in the new era of private colleges.
\end{abstract}

\section{Introduction}

"Belt and Road Initiative" for the future period of China to promote the strategic economic development, through the development of the construction of the economic zone, to promote the communication and cooperation of international economy and culture, realize the development process of international economic integration area, promote the integration of national culture development countries. "The Belt and Road" economic development strategy to guide China's economic entity, product, culture, technology and talent to go out and achieve collect income and improve the level of development of the national economy at the same time, more conducive to China international status and influence, promote the balanced development of international economy and raise the level of overall development. Private colleges and universities as an important part of higher education in China, shouldering the arduous task for the future of high-quality professional talents, how to meet the development needs of the times, the times higher education has become a need to study and solve the problem of private schools, "the development of a road with a" strategy not only further promote our country's the opening level of development, at the same time to achieve the docking of China's higher education and the international advanced level, and continue to deepen the teaching reform of higher education in the field of private universities to improve the teaching level and teaching quality, become the important opportunities and challenges during the period of private universities in the future, in-depth analysis of the concept of Education under the new situation, has important strategic the significance of comprehensive school level.[1]

\section{"Belt and Road Initiative" development strategy connotation and advantage}

"The connotation of development strategy of The Belt and Road". The development strategy of "The Belt and Road" refers to Silk Road Economic Belt, maritime Silk Road, is president Xi Jinping for the future period to achieve further open up new economic development strategy for the development of our country, in economic development, and promote cultural communication between countries and regions and fusion, in the ancient Silk the road route as the carrier, adhering to peaceful cooperation, openness and tolerance, mutual learning and cooperation spirit, realize along 
the country's economic and cultural exchanges and mutual learning spirit, realize peoples common development and shared prosperity and civilization harmonious life.

"Development strategy The Belt and Road" advantage. The strategy for the development of The Belt and Road "to further promote China's opening up development level, will strengthen communication and cooperation with neighboring countries, Central Asia, West Asia and Europe countries has become a major development strategy, not only contains the basis of coordinated development of economy, and the culture and talent communication, further confirms the open and inclusive concept of cooperation, formulate the strategy provides a new way to solve the present existing overcapacity and economic transformation, also play a vital role for promoting the development of the international economic integration development. Construction of The Belt and Road Economic Zone, the economic belt along the countries and regions linked to the formation of the economic development community, not only to achieve the interoperability of exchanges and cooperation. More established a new line of human development. The strategy for the development of The Belt and Road "not only for the region along the economic development of our country pointed out a new direction, and puts forward some new ideas and new ideas for regional development of education in our country, to provide important opportunities for development to improve the education quality, deepen the education reform.[2]

"The construction of The Belt and Road" economic zone development strategy to implement the actual work, not only need to increase communication and cooperation between the government, part of NGO exchanges and dialogue is also essential, to promote economic and trade cooperation between countries and regions, but also dig out the countries and regions of the cultural heritage and cultural connotation. The humanities, science and technology, education, environment and other areas of communication and cooperation between countries of communication and economic development of the liberalization of normalization. At the same time to improve the economic environment brought more employment opportunities for the society, the background of higher education to the development of the times, with professional knowledge, with new channels for employment and entrepreneurship oriented education become the requirements of the new target.

This private college teaching situation, need to clear direction of reform of education ideas, give full play to their existing education management system, personnel training system, curriculum and other advantages, the new educational goal into the philosophy of education, the realization of "Belt and Road Initiative" development strategy under the new situation of development.

\section{The analysis of the current situation of private higher education}

Private higher education idea compared with public institutions of higher education, has the characteristics and advantages of great flexibility, but based on the "The Belt and Road" strategic development though there are many prominent problems restricting the scientific development under the new situation.

The lag of educational ideas and school running ideas; With the rapid development of education industry in recent years, private universities also ushered in the high-speed development period, the school continues to expand the scale and level of education have been significantly improved, but in its educational philosophy and ideology, there are a lot of private schools did not play to the characteristics of their own advantages and characteristics, follow and imitate the public higher education school teaching ideas and teaching mode and teaching methods, the lack of independent innovation and development of teaching philosophy. There are many schools will be running too much money into the concept of color blind teaching scale expansion and education settings, not for their own teaching resources and educational load carrying capacity comprehensive consideration, seeking to expand enrollment to increase the return to education, increase teaching income, a serious violation of the fundamental purpose of higher education at the same time, it is difficult to realize the scientific development of private colleges.

The curriculum is unreasonable. At present, many private universities set courses are in accordance with the relevant provisions of the Ministry of education, School of higher education 
teaching system of professional curriculum design or copy, according to the urgent needs of talents, but ignored its professional education actual strength to meet the teaching needs, not according to their own educational and professional background the advantages, curriculum characteristics of outstanding professional education and the education level of brand building, teaching many students in course learning is not able to achieve professional scientific research level, while there is no occupation education professional practice, lack of education development in line with its own curriculum and reform.[3]

Teachers and scientific research forces are relatively scarce. Many private universities established time is short, compared with the public schools of higher education, there are great teachers education drawbacks, although in the teaching or teaching environment, many private colleges have obvious advantages, but the purpose and essence of higher education or teaching itself, lack of teachers to achieve the level of comprehensive private colleges and Universities to improve. At the same time, many private colleges are the serious shortage of scientific research strength, private colleges and universities lack of basic scientific research, even if the funds have advantages, outstanding talents in research and education is not willing to carry out scientific research and education activities in private colleges, private colleges have not formed the platform to carry out research work, it also restricts the educational level and quality of private universities upgrade.

The target of talent training is not clear. Private college students generally did not reach the public higher education undergraduate school admission scores of students, although many regions have canceled between public and private universities score differences, but in many areas, the students in the examination, there would still be inclined to choose public university priority, the quality of private college students compared to the public the University has some disadvantages. In the teaching process of private universities, private universities are not combined with its own characteristics of the source of clear educational objectives and teaching plans, but the public university teaching copy, students can not meet the actual needs of learning, not for education and teaching from their own perspective, so students in the end in higher education, neither professional nor practical embarrassment, it is difficult to achieve good students employment process.

\section{The influence and change of the idea of private colleges and Universities under the new era}

The development strategy of "The Belt and Road" is not only a great opportunity for reform of higher education in China, but also the important mission entrusted by history, be able to develop more high-quality professional applied talents, serve China economic development, as The Belt and Road along the national service, has become an important issue in higher education. Private universities should make full use of their own educational advantages, adjust their educational ideas and school running ideas, and realize private higher education in line with the needs of the times and the future direction of development.

Private colleges and universities should change their basic educational ideas and ideas and develop their own advantages in running schools. Management of private colleges' ideological level affect their own educational philosophy directly, managers should be from their own point of view, to realize the educational significance, abandon the for-profit education philosophy, education will implement the focus to the quality of education and improve the educational level of the. The public and private universities have different system, their own operating conditions may affect the level of school management, but also of the private universities should pay attention to the problem, but the profit is not the only purpose and the fundamental purpose of the core value of private colleges is to enhance the value of their own society and education. Private colleges should combine their own existing educational advantages, the mode of operation and the education market to actively expand the fusion and development of the existence of their own educational advantages, to achieve a win-win situation to improve the quality of education and operating income, improve the quality of education in Colleges and universities only education and social influence, to promote the private colleges and universities to enhance economic benefits, achieve the sustainable development of private universities.[4] 
Private colleges and universities carry out reasonable professional settings. "The development of The Belt and Road" strategy for the birth of the great demand of professional talents in agricultural production, agricultural technology, high technology, economy, foreign trade, logistics, English as foreign language, law, finance and other fields will become a hot social professional jobs, private colleges and universities to clear the education of their own position, to high quality education resources in our country as the basis for training of professional education and seize the opportunity to grasp the pulse of the development of education, office of higher education has its own characteristics. Professional learning is a training cycle characteristics of private universities, professional setting is highly forward-looking, now based on the background of comprehensive analysis and control, the future may become a hot social demand for professional talents as a professional learning direction, reasonable teaching arrangement and professional settings, in order to meet the development demand for talent the.

Improve the quality of teachers and scientific research;Although there are disadvantages of private college education resources of teachers and scientific research strength is insufficient, but also has the advantage of flexibility of education, private universities should make full use of their own advantages, get rid of the shackles of the education system, the social power quality education into the private universities in the teaching system, mining of outstanding talents of the social resources, to professional education, so that students can not only fully understand and master the basic knowledge of textbooks, and the actual demand for social work to get a deeper understanding of the combination of theory and practice of education practice. Private universities can also carry out education cooperation mode and "The Belt and Road along the country, foreign language education resources, excellent foreign trade education resources into the private universities teaching system, at the same time, our country has the advantage of agricultural education resources, high-tech materials to the higher education system in foreign countries, implementation of quality education resources the win-win cooperation.

Make clear the target of personnel training, and carry out higher education with professional talents. Private colleges and universities to educate their own actual in-depth analysis, the formation of professional talents in higher education can meet their own development needs of the education on the basis of the structure of education, the curriculum can work with the actual needs of employment and entrepreneurship. In the practical education work, should pay attention to the theory and practice of combining content, so that the students can not only have a comprehensive grasp of professional knowledge through professional learning, and be able to meet future employment or business needs, have good personal qualities and comprehensive occupation accomplishment. At the same time, private colleges can also be carried out between the students learning exchanges and international schools of higher education, let the students to "The Belt and Road along the country's actual conditions, economic development and talent demand are able to understand, to enable students to clear their future employment orientation, targeted language and professional skills improvement and promote the students through the process of education in private colleges, a foothold and useful in the wave of the future economic development, contribute to the implementation of the strategy and development of national economy.[5]

\section{Concluding remarks}

Private college education system has obvious advantages, the development of colleges and universities should base on their own advantages, to conduct a comprehensive analysis on the situation of education itself, and it has high forward-looking educational ideas, clear school and education goals of higher education to meet the needs of the development of the times, to ensure the students through the process of higher education to meet future employment business needs, to achieve practical application in higher education. 


\section{References}

[1]Mohammadi G. The influence of age, seat belt, time of day, and type of vehicles on road accidents in Kerman, Iran[J]. Traffic Injury Prevention, 2009, 10(2):191.

[2]Liu Z M, Liu L, Shun-Shun H U. On the Process of Mass Higher Education of 73 Countries along the 'Belt and Road' Initiative Regions[J]. International \& Comparative Education, 2016.

[3]Liu J, Education S O. Chinese higher education and the one-belt-and-one-road initiative[J]. Journal of Hebei Normal University, 2016.

[4]Zhang Z H, Xing-Mei L I, Cai J F, et al. Opportunities and Challenges of Forensic Science Education under the "Belt and Road Initiative" Strategy[J]. Education Teaching Forum, 2016.

[5]Qingcheng L I, Liu Y. Exploration on the Ideas and Paths for Characteristic Local University Internationalization under "the Belt and Road Initiative" [J]. Chongqing Higher Education Research, 2016. 